\title{
The Regime Complex for Food Security: Implications for the Global Hunger Challenge
}

\author{
Matias E. Margulis
}

\begin{abstract}
Recurrent food price crises, coupled with the steady deterioration of world food security over the past two decades, have prompted efforts to reform the global governance of food security. This article argues that diverging rules and norms across the elemental regimes of agriculture and food, international trade, and human rights over the appropriate role of states and markets in addressing food insecurity are a major source of transnational political conflict. It analyzes (1) the role of norms in the construction of the international food security regime; (2) the transition from an international food security regime to a regime complex for food security; and (3) rule and norm conflicts within this regime complex. It concludes with a discussion of the impacts of diverging norms on the politics of regime complexity and its policy implications for current efforts to reform the global governance of food security. Kerworos: regime complexes, food security, trade, human rights, WTO, UN.
\end{abstract}

FOOD SECURITY HAS REEMERGED AS A MAJOR ISSUE IN GLOBAL GOVERNANCE. The perfect storm of surging energy prices, biofuel policies. food trade bans, and speculation on commodities markets that drove food prices to historical peaks in 2008 swelled the number of hungry people worldwide to an unprecedented 1 billion. Although the number of hungry persons has fallen slightly since then, food prices spiked sharply again in 2010 and 2011 and uncertainty about the avalability of the world food supply continues to send jitters across global markets. Polities have also felt the repercussions of volatile and rising food prices. Let us not forget that the calls for "breat and lreedom" became the rallying cry for the political movements in Egypt and Tunisia that toppled long-standing autocratic regimes. Chinese and Indian authorities have declared rising food prices a major macroeconomic concern that threatens both economic growth and social stability.

The recent food price crises exacerbated an alleady deteriorating world food security situation. Following a steady decline in the number of hungry people worlelwide between 1970) and 1995. the global trend has since reversed, with world hunger continuously on the rise ever since.' This backward movement was unexpected and has surprised most policymakers. Current trends indicate that the first Millemmium Development 
Goal (MDG) - to reduce the number of hungry people worldwide by half between 1990 and 2015-will not be met. A further concern is the domino effect of rising food insecurity: higher levels of undernutrition and malnutrition will undermine progress on other MDGs such as global health and social and human development.

There is now a wide acceptance among policymakers of the pressing need to reform the global governance of food security in order to address rising world hunger and improve the efficacy of existing food security interventions. It is widely acknowledged that the global scale, drivers, and complexity of food insecurity are beyond the capacity of individual states to manage alone. The current global reform drive includes increasing cooperation and policy coherence across the UN system, the Bretton Woods Institutions, regional bodies, and the Group of $20(\mathrm{G}-20)$ leaders. However, the hunger problem cannot be simply reduced to issues of poverty and food supply, which is the focus of current policymaking. World poverty has been constant-and even declined slightly-during the period in which hunger grew: ${ }^{2}$ Rising hunger has occurred alongside constant growth in world food production. in both absolute and per capitat terms. While poverty reduction remains an important factor. there are other factors that need to be taken into account. As the recent food price crises demonstrated, the drivers of food insecurity are increasingly complex and tied to structural changes in the global food economy. Demand for international cooperation will only increase. Climate change is predicted to exacerbate food insecurity in developing countries and will further intensify the challenge of sustainably feeding a world population of 9 billion by 2050$)^{+}$

The study of regime complexes is significant to the current debates about reform of the global governance of food security. There has been a transition from an international food security regime to a regime complex for food security, and this has major implications for efforts to improve policy coherence and the institutional architecture 10 address world hunger. Diverging rules and noms across the elemental regimes of agriculture and food. international trade, and human rights concerning the appropriate role of states and markets in addressing food insecurity produced a simmering transnational political conflict prior to the recent food price crisis. Inderstanding this conflict is critical because it is unresolved and therefore is a latent tension forestalling efforts to reform the global governance of food security.

\section{The Construction of}

\section{the International Food Security Regime}

A major research program in international relations has explored the role of the intersubjective dimension of human action in constructing the global 
polity. Norms, ideas, and identities play a critical role in structuring international relations alongside material factors. Norms are the underlying cognitive frameworks that shape actors' identities and preferences and construct the principles, rules, and institutions that constitule the international system. Drawing from these insights. I trace how food security has been constructed as an issue area requiring international cooperation and the consolidation of an intermational food security regime over time. This historical narrative is critical to understanding the continuous evolution of international food security governance and its current historical juncture.

Eradicating hunger was one of the principal objectives of the postwar international system. Alongside the desire for peate and prosperity, the architects of the postwar system, led by the United States, held a belief about the international community's collective responsibility to fight hunger and the vast potential for advances in mutrition and agricultural science to achieve this end. This belief drove the creation of the Food and Agriculture Organization (FAO) in 1945, the first UN specialized agency tasked to raise world nutrition levels, improve food production and distribution. and ensure humanity's freedom from hunger. ${ }^{7}$ Early FAO efforts sought to address the food problem through the international coordination of grain production and trade to redistribute surplus food produced in the West to meet the needs of the hungry in the developing world. However. the United States and other major grain producers, who enjoyed unique positions at that time as the world's granaries and preferred expanding agricultural trade. did not fully support international coordination and instead stecred the FAO to focus its work on strengthening food supply management within developing countries.

In the 1960 s, rapid population growth. combined with lagging food production in developing countries, prompled Mallhusian fears of an impending world food shortage. It was during this period that the UN World food Programme (WFP) wats created under the umbrella of the FAO to provide food assistance to developing countries. While this development served multiple humanitarian. trade. and domestic farm policy objectives of the main aid donors, such as the United States, the European Community. Canada. and Australia (also the major grain producing countries). the evolving practice of international food assistance further concretized the norm and expectations of international cooperation on hunger." The creation of the WFP was quickly followed by the major grain-producing countries agreeing to a new international food aid burden-sharing system under the Food Aid Convention (FAC). In addition to food aid, these countries scaled up bilateral and multilateral assistance to foster food production in developing countries by financing technological transfers and the introduction of higher-yield seed varieties. fertilizers. and pesticides (i.e., the Green Revolution). 
The term food security was first incorporated into international policy during the early 1970s. An unexpected shortage of wheat caused panic on international food markets that drove grain prices skyward. Food-importing countries - the vast majority of states - desperately scrambled to secure food supplies. This was the first recognized world food crisis and it led to severe hunger in many countries. The crisis revealed a new driver of hunger to policymakers: price volatility and the unreliability of food supply on international markets. ${ }^{9}$ The events of 1972-1974 challenged assumptions about how world food markets worked and led to political consensus about the need for new instruments of international cooperation to eradicate hunger. Several new international institutions came out of the 1974 FAO World Food Conference, including multilateral forums for interstate cooperation and an international financial institution. the International Fund for Agricultural Development (IFAD), to address the new drivers of food insecurity. ${ }^{10}$ Although the conference produced political consensus about the need to address food security. the return of stability on international food markets soon after it was held diminished the sense of urgency for major international market reform.

The concept of food security continued to evolve, incorporating advances in the understanding of the causes of hunger. In particular the work of Nobel Prize-winning economist Amartya Sen, which demonstrated that access to food and not just food supply was critical to averting famine. reoriented international policies to look beyond traditional food production and supply issues. "Sen's theory of entitlements recognized that there were multiple causes of hunger, including food supply, availability, utilization. and access. ${ }^{2}$ This new idea prompted a major rethinking of international food security policies away from the emphasis on bulk food transfers toward incorporating a set of interventions that target various dimensions and scales. This multifaceted understanding of hunger became the basis of the international consensus definition of food security negotiated by states at the 1996 World Food Summit. ${ }^{13}$ This definition remains the accepted basis for international and national food security policymaking.

Taken together, these developments shaped the construction of food security as an issue area and the formation of an international regime around it. The desire to eradicate hunger alongside an evolving understanding of food security was reflected in the institutional arrangements and practices of international society. At the core of the international food security regime, and what differentiated this regime from the agricultural policy regime's focus on expanding consumption, production, and trade, was the widely accepted principle of international, collective action to eradicate hunger and reduce the number of persons who suffer and die from hunger and malnutrition. The institutionalization of this regime is most commonly 
associated with the Rome-based UN food agencies: the FAO and its offshoots, the WFP and IFAD. The work of these institutions was grounded on shared principles and understandings of food security, with each institution performing a unique function: the provision of interstate negotiation and an information clearinghouse, the delivery of and standard-setting for international food assistance, and the provision of long-term loans, respectively. Other international institutions were key parts of the international food security regime. However. they varied in centrality and type, ranging from the short-lived World Food Council (1974-1994), a ministerial-level body tasked with keeping food security on the political agenda, to the Standing Committee on Food and Nutrition, which continues to ensure policy coherence across the UN system. Institutions outside of the UN system were also embedded in the regime, such as the FAC and the Consultative Group on International Agricultural Research, a network of international agriculture and food research centers nominally under the World Bank. While these latter institutions had variegated linkages to the UN institutions, there was a shared understanding among them about what food security meant and an underlying principle-eradicating hunger-that girded their work.

\section{From International Food Security Regime to a Regime Complex for Food Security}

There has been a shift from an international food security regime to a regime complex for food security. This shift occurred in the 1990s when institutional proliferation resulted in overlapping authority among the international food security. international trade. and human rights regimes. This has assembled a set of institutions with diverging noms and rules into a regime complex formation.

The creation of the World Trade Organization (WTO) in 1995 was a decisive moment in the emergence of a regime complex for food security. In particular, the Agreement on Agriculture (AA) and the Agreement on the Application of Sanitary and Phytosanitary Measures (SPS) brought agriculture and food governance under the binding international law of the WTO. The A A encompasses specific rules that determine the policies that states are permitted to undertake in order to achieve food security. ${ }^{14}$ This includes. for example. domestic food subsidies and direct food assistance, types of border protection and financial support permitted to strategic food security commodities, export bans, and the operation of food reserves. The AA also contains rules on the provision of international food aid.

From the onset, the WTO acknowledged that international trade rules could have consequences for world food security. A key objective of the AA was to reduce agricultural overproduction in developed countries that was 
seen widely as the cause of a vicious cycle of low food prices, farm crises. and a transatlantic agricultural subsidy war. ${ }^{15}$ During the negotiations of the AA. developed countries sought to boost the price of agricultural goods. reduce the burden of farm subsidies on national budgets. and maintain protection for domestic agricultural interests. It was recognized that success in achieving these objectives could carry negative food security implications such as higher food import bills for net food-importing developing counties. Therefore, the AA's framework explicilly charges the WTO and its members with continuously monitoring the impact of trade reforms on world food security and, if necessary, with providing assistance to countries that experience difficulties in financing food imports. ${ }^{16}$ The SPS also governs food security because it sets the international standards for food safety. It provides the framework and conditions under which states may implement trade restrictions, such as on the import of foodstuffs that pose risks to human health. Presently, the AA and SPS are under renegotiation ats part of the Doha Round (2001-present) of multilateral trade negotiations. ${ }^{17}$

The WTO's binding rules and strong dispute settlement system give it significant authority in governing food security. Its broad coverage of food security in the AA and SPS created new linkages with the international food security regime. It introduced to the complex a very different normative orientation to the global governance of food security than had previously existed. The WTO's objective is to liberalize world agriculture along market-oriented principles. including rules that seek to limit state intervention that is perceived to distort self-regulating markets. At the WTO, trade officials argue that agricultural liberalization is key to increasing global food trade. which they associate with enhancing world food security.

The international human rights regime also has taken on greater authority in the global governance of food security by promoting the human right to food. The human right to food is not a new concept. It was first articulated in the 1948 Universal Declaration of Human Rights and then given legal character in the 1966 International Convention on Economic, Social, and Cultural Rights, which obligated parties to progressively realize the right to food and ensure an equitable distribution of world food supplies in relation to need. The right to food took on greater salience when states agreed to clarify the definition and the rights and obligations implicit in this human right as an outcome of the 1996 World Food Summit. The obligation of states to respect, protect, and fulfill the right to food is now an accepted international norm. Moreover. the right to food is becoming ever more institutionalized. International guidelines on the right to food were negotiated by states in 2003 . While these guidelines are not legally binding. they further specified states obligations and devised a framework for national legislation and international cooperation on agriculture, development. and 
international trade issues. ${ }^{18}$ The monitoring and enforcement capacity on the right to food hats been significantly strengthened under the work of the Office of the High Commissioner for Human Rights: the Commitlee on Fconomic. Social and Cultural Rights: and the Human Rights Council. The latter has developed enhanced processes to receive and respond to violations of the right to food and, thus, there are greater reputational costs for states and nonstate actors that violate this right.

An increasing number of states, such as South Africa. Brazil, and Indial, have created constitutional frameworks to protect the right to food. Admittedly, not all state actors fully support the expansion of the human rights regime's authority and the spilling over of human rights into the food security debate. Nevertheless, there is growing international consensus that the right to food is a critical dimension of food security beciase it defines the obligations of states to ensure that access to food is not diminished by other policies, particularly for the most vulnerable groups in society. Food as a human right, a right implicit with national and international legal obligations. is a new and important norm in the regime complex for food security. The linkage between food security and the right to food creates new expectations among citizens and other actors for state action to promote food security.

Global food security governance has the characteristics of a regime complex. identified by Amandine Orsini. Jean-Frédéric Morin. and Oran Young in this issue. In the regime complex for food security, there is an overlap of three elemental regimes-agriculture and food. international trade, and human rights - characterized by different norms that deal with a common issue, food security. These elemental regimes exhibit overlapping memberships as most states are memhers of the FAO and WTO or have signed on to the relevant international human rights treaties.

\section{Overlapping Rules for Food Security}

Scholars of regime complexes alert us to the impacts of overlapping rules on international cooperation and the myriad strategies employed by states and other actors in response to such situations." Overlapping rules can introduce uncertainty, cause coordination problems by altering the incentives for international cooperation, and encourage forum-shopping and forum-shifting behavior among participants (see Michael J. Struett. Mark T. Nance. and Dianc Armstrong in this issue). ${ }^{21}$ On the other hand, overlapping rules, once acknowledged by states ats a constraint on cooperation. may in fact prompt direct efforts to increase coherence across the elemental regimes (see Jean-Frédéric Morin and Amandine Orsini in this issue). Overlapping rules in the regime complex for food security increase uncer- 
tainty for policy actors and have been a source of transnational conflict between states and international organizations.

Consider the case of international food aid rules. Historically, international food aid rules rested with the original international food security regime. specifically under the FAO and FAC, that over time established best practices for international food aid, including minimizing potential negative impacts on food trade. ${ }^{21}$ This situation changed when authority over food aid rules was rescaled with the creation of the WTO. The AA linked trade and food aid in a new way; it included explicit references to the existing FAO and FAC food aid rules as criteria for determining if a WTO member's food aid policies were legitimate aid or a disguised farm subsidy. This particular development, which broke with the long-standing preference by most developed countries to keep food aid issues ont of the General Agreement on Tariffs and Trade and the World Trade Organization, was the result of trade tensions and not humanitarian concerns. Having the AA cover food aid was viewed by many grain-producing countries as a means to keep questionable US food aid practices in check. such as the use of food aid to gain a commercial foothold in foreign markets. As a result. food aid became deeply entangled in the politics of international trade. 2

The linkage between the food security and trade regimes has led to greater interaction among international and transnational policy actors. And this includes greater political friction among these actors. For example, when the current FAC expired in 2002 and was due to be renegotiated, states agreed to postpone renegotiating it until the WTO negotiations were finalized. This outcome was imposed by the trade ministries of the advanced economies on their international aid counterparts. Trade officials feared that renegotiating the FAC concurrently with the AA could result in forum shopping and the potential watering down of international food aid rules. Development officials hoped the renegotiation of the FAC would provide the opportunity to finally update the rules to reflect new best practices for international aid. Suspending the FAC renegotiation was publicly criticized by nongovernmental organizations (NGOs) active in humanitarian assistance, which cited this as further evidence of the WTO's "chilling effect" on other policy fields. ${ }^{23}$ Development officials were similarly disconcerted about trade politics apparently trumping development issues. Food aid policy experts argue that freezing the FAC renegotiation for reasons related to trade policy derailed the political momentum that had been building among international development agencies to modernize the FAC to address rising global food insecurity. ${ }^{2+}$

Overlapping rules and negotiations of food aid rules at the WTO also impacted the WFP. While the WFP is not involved in formal food aid rule making, nor is it formally linked to the WTO under the AA. this institution 
plays a key role in food aid delivery (it delivers the majority of multilateral food aid) and as a key forum for developing best practices. During the carly years of the Doha Round, WFP officials expressed strong reservations about some WTO members' proposals that would increase the WTO's authority over international food aid. For example, one 2003 proposal supported by most WTO members envisaged the multilateral trade regime as the final arbiter of what is legitimate (and. by extension. legal) international food assistance. Given a lack of formal capacity to intervene in the statebased negotiations at the WTO, WFP officials resorted to launching an international media campaign critical of the WTO food aid proposal on the eve of the 2003 WTO ministerial meeting in Hong Kong. ${ }^{25}$ The WFP's forceful and highly public critique of the WTO proposal came as an unexpected shock to many trade negotiators and prompted reconsideration by WTO members of the content and implications of future WTO food aid rules. The case of the WFP and WTO food aid rules illustrates that regime complexes can produce transnational political conflicts related to actors perceptions of hierarchy, even when there are no formal overlapping rules or institutional linkages.

\section{Norm-based Conflicts and Food Security Governance}

Norm-based conflicts are evident in the regime complex for food security. There is considerable transnational political contestation surrounding the impacts of trade liberalization on food security and the appropriate global policies required to mitigate any negative consequences. This contest is played out within the regime complex for food security, with the WTO and UN institutions being influential actors.

Diverging norms between the WTO and the UN institutions over the state-market relationship and its role in world food security frame this conflict. The WTO views free trade as being supportive of world food security: this position is the official view of the WTO secretariat and also of the powerful proponents of agricultural trade liberalization (e.g.. the United States. European Union. Brazil, Canada, and Australia). ${ }^{26}$ The FAO and UN human rights systems acknowledge the potential of trade liberalization to improve rural livelihoods. However, these institutions" support for international trade is tempered by the recognition of asymmetrical power relations where powerful food-exporting countries and several transnational agrifood companies disproportionately shape market outcomes. The UN institutions are mandated to address the needs of food-insecure people and they contend that free trade does not necessarily enhance access to adequate food. UN institutions target the WTO negotiations because trade rules are binding on states, especially food-insecure ones, and this creates uncer- 
tainty for states on how to reconcile potential trade and human rights obligations. Norm-based conflicts have prompted the UN institutions to seck to influence international trade rules so that states have recourse to a wide set of policy measures to regulate national and international markets to achieve food insecurity objectives. including the obligation of states to protect the right to food under international law. In short, the UN monitors (and seeks to influence) trade negotiations with an eye toward ensuring that food security concerns are not lost to horse trading in the final deal.

It would be a mistake to equate these divergent readings of trade and food security as symptoms of bureaucratic turf wars. For example, the FAO strongly supported the creation of the WTO and provided developing countries technical support during negotiations of the AA. Since 1995, the FAO has cooperated closely with the WTO on many policy and technical issues. The FAO has never sought authority over agricultural trade negotiations. Instead, conflict between these institutions arises from the FAO's assessment that the AA is unbalanced and favors Northern agriculture interests. This view is shared by most developing countries, which make up the vast majority of WTO member states.

Diverging norms also engender problems of trust among actors. For example, international trade and human rights officials remain skeptical about each other's intentions, in large part because there is a concern that efforts to reconcile international trade and the right to food will lead to the weakening of one system at the expense of the other. Recent discourse about aligning trade and human rights is encouraging: however, scholars have noted the necessity for social learning and cultural change among international and national officials to bridge the current normative chasm. ${ }^{27}$

A new political dynamic in the regime complex for food security is heightened disagreement among old and new powers over food security and the role of international trade. Developing countries at the WTO-in particular the Group of 20 (G-20), a Southern bargaining coalition on agriculturewith the support of the Group of $33(\mathrm{G}-33)$ coalition of developing countries with agricultural sensitivities. have pushed for new trade provisions to support food security that would protect key basic food staples and other crops produced by resource-poor farmers from being subject to further liberalization. One measure, the so-called Special Safeguard Mechanism (SSM), is intended to provide developing countries with the right to raise import tariffs on a temporary basis for sensitive food security crops. In theory, the SSM would prevent the rapid inflow of foreign, subsidized food imports, which cause food prices to bottom out and can wipe out small farmers. Another measure under consideration at the WTO, the "special products" proposal, would permit most developing countries to negotiate for a lower overall cut to the tariffs on products designated as critical to food security. 
Developing countries claim these measures are vital to promote world food security. FAO officials have long supported these types of measures. including providing technical support to the WTO and developing countries during the development of these measures. More recently, the UN special rapporteur on the right to food. Olivier De Schutter, has recommended that WT() member states adopt these instruments. suggesting that these are consistent with states' obligations to protect the right to food. Developed countries claim these two instruments are protectionist and contrary to the spirit of the WTO's agenda of progressive trade liberalization. By extension. there is a concern that the SSM and special products may further expand the WTO's authority into food security.

The conflict over the extent to which the WTO and the AA should accommodate food security has proved to be a major source of political deadlock in the Doha Round. Breaking the WTO deadlock will likely require that new trade-related food security instruments be accepted: this is ever more true after the recent global food crisis. By implication. this will require grealer permissiveness by WTO members to support more, not less, state intervention in agricultural markets. The actual political economy implications of this are unclear: however, it does suggest potentially less market access for the major agricultural exporters. The normative tensions are profound here because what is at stake is tacit recognition that the WTO's mandate to reform agricultural trade along market lines needs to be reevaluated in light of global food security concerns. The WTO secretariat and many WTO members recognize and are disconcerted by such an outcome because they fear this may unravel not just the agricultural negotiations, but the entire Doha Round of negotiations, and thereby endanger liberalization on industrial goods and services.

While the WTO has significant regulatory authority in the regime complex, the moral authority continues to rest with the UN institutions rooted normatively in the international food security and human rights regimes. As such, there is no clear solution to addressing norm-based conflicts in the regime complex for food security. Centralization is an unlikely outcome. Increasing the authority of the WTO over food security will be strongly opposed by the UN system. the WTO, most states, and $\mathrm{NGOS.} \mathrm{At} \mathrm{the} \mathrm{same} \mathrm{time,} \mathrm{most} \mathrm{states} \mathrm{will} \mathrm{continue} \mathrm{to} \mathrm{value} \mathrm{the} \mathrm{strong}$ rule-based system of the WTO in spite of the current difficulties in the Doha Round. As such, states are unlikely to delegate responsibility for agriculture trade policy to the UN system. This would undermine the authority of the WTO and require states to recalculate the benefits and costs under all of the existing WTO trade agreements without agriculture on the lable. Indeed, that option could cause further breakdown of the multilateral trade regime. 


\section{Implications for the Twenty-First-Century Food Security Challenge}

The global governance of food security is at a crossroads. On the one hand, international efforts to reduce world food insecurity have fallen considerably short of expectations and commitments. There is a broad agreement that the current levels of world food insecurity are unacceptable morally and ethically as well as from a social and economic development policy perspective. The current state of world food insecurity is a dark stain on the record of international cooperation given that the tools and technologies to mitigate food insecurity among the most vulnerable are well proven, widely available, and inexpensive. On the other hand, there are signals that herald measured optimism. Food insecurity is a now a priority issue in global governance. This is evident in the recent work programs on food security. including the Group of 8 (G8) 2008 L'Aquila Food Security Initiative and the 2012 New Alliance for Food Security and Nutrition programs to support agricultural production, technology, and research; and the establishment of the Global Agriculture and Food Security Program. a multidonor fund to support private and public investment in agriculture, managed by the World Bank. It is also evident in the deepening transnational food security policy network at the UN High-Level Task Force on the Global Food Security Crisis and Committee on World Food Security. Greater cooperation at the regional level on food security is also promising. such as efforts by the African Union to increase the share of the national budget devoted to agriculture and the near completion of the Association of Southeast Asian Nations (ASEAN) Plus Three Emergency Rice Reserve.

Returning to the present multilateral efforts to address global food insecurity, we can observe many of the conflicts latent in the regime complex already at play. Diverging norms over trade liberalization are visible in the current debate on food export bans by major grain producers such as Russia and Ukraine. The WTO. World Bank, and G-8 blame unilateral export bans for high food prices and call for trade rules to prohibit states from using them in the future. By comparison, the UN institutions are aware that many poor countries also resort to bans in times of uncertainty and they have called for greater transparency and coordination of international food supplies, but have not fully endorsed an outright prohibition on export bans. If there is agreement on disciplining export bans, this is likely to require granting greater authority to the WTO given that its rules cover agricultural export bans. WTO rules are likely to be limited to reducing the negative impacts of export bans on international market actors. However. WTO rules are unlikely to be crafted in a manner to directly minimize the negative impacts of price swings on particular groups of food-insecure individuals, which is precisely what would be demanded by the norms of the interna- 
liomal food security and human rights regimes. Another cxample is the resistance by the G8. WTO and World Bank to the UN's attempts to matinstream the right to food as a central pillar of the multilateral response to the food crises. The former are major proponents of lade liberalization and are concerned that a rights-hased framework may encourage developing countries to dectease their reliance on international markes and place a greater emphasis on food self-sufficiency. 2 '

The recent appearance of the Gis. G-20. and World Bank as key actors in global food security governance is notable. and it is evidence of the increasing density in the regime complex for food security. Even more significant is the emergence of a potential new and fourth elemental regime in the complex, international finance. There is now a consensus that financial speculation is a major driver of rising and volatile food prices. The $(j-20$ finance ministers and intenational organizations are working on regulatory options to reduce food price volatility and this may cover financial speculation in atgricultural commodities. Similat to international trade. a mascent conflict can be observed within the regime complex: there is a strong divergence of views between the lnited States, international financial institutions. and private actors (which are resistant to new public forms of regulation of commodities trading) and France, most net food-importing developing countries, the UN system, and global civil society (which strongly support greater regulation of financial markets). It is premature to speculate on the longer-term implications of this possible expansion of the regime complex for food security. However, it is clear that the linkages between food security and international finance are recognised by actors ats significant and warranting international cooperation.

Going forward, diverging norms and rules are likely to remain a source of conflict and fragmentation in ongoing efforts to strengthen the global governance of food security. It is essential that policymakers recognize the existence and chatacteristics of the regime complex for food security and seek new ways of forging consensus among multiple and conlicting norms and rules. A failure to recognies the interlocking relationship among the elemental regimes of agriculture and food, intemational trade, and human rights is likely to impede international cooperation to reduce world hunger.

\section{Notes}

Matias I: Margulis is an assistan professor of intemational sludies at the liniversity of Northern British (obumbia. The atuhor thanks Kristen Hopewell, Marieve Dubois. Hector Mackengie. Weldon Epp, and participants of the 20lo Recherehe et Bnseignement en Politiguc Internationale workshop "Isute-I inhages and Regimecomplexes" and the 2011 Alliance lor Governance Research and Analysis work- 
shop "Institutional Diversity in the Governance of the Global Economy" for comments on an early version of this article. This research was supported by the Cadicux-léger Fellow ship from the Department of Foreign Affairs and International Trade Callitda.

1. Food and Agriculture Organization, The State of World Food lnseremin (Rome: FAO. 2010).

2. World Bank. "Poverty Trends." http:/web.workbank.org/wbsite/external /topics/extpoverty/0..contentMDK:22569498 pagePK:148956 piPK:216618 the SitePK:336992.00.html (accessed 24 February 2011).

3. Food and Agriculture Organization, The State of Fond and Agriculture. Biofivels: Prospects. Risks and Opportunitie's (Rome: FAO, 20(69).

4. See Jennifer Clapp. "The Global Food Crisis and International Agricultural Policy: Which Way Forward?" Global Golemance 15, no. 2(2009): 299-312: Food and Agriculture Organization. How to Feed the Horld in 2050 (Rome: FAO. 2009).

5. John G. Ruggie. Comstructing the World Politw: Exass on International Institutionalisation (London: Routledge. 1998).

6. Martha Finnemore and Kathryn Sikkink, "Taking Stock: The Constructivist Research Program in International Relations and Comparative Politics." Ammal Revien of Political Science 4 (200)1): 391-416.

7. Food and Agriculture Organization, Comstitution of the Fosd and Agriculuwe Orgamization (Rome: FAO. 1965).

8. D. John Shaw. World Foed Security: A History Since 1945 (Basingstoke: Palgrave Macmillan, 20(17).

9. Matias E. Margulis, "Global Food Governance: The Committee for World Food Security, the Comprehensive Framework for Action and the G8/620," in Rosemary Rayfuse and Nicole Wiestelt, eds.. The Challenge of Fond Security (Cheltenham: Edward Elgar Publishers. 2012), pp. 231-254.

10. United Nations. Report of the World Fond Conference, 5-16 Noremher 1974 (Rome: Food and Agriculture Organization. 1974).

11. Food and Agriculture Organization. Trade Reforms and Food Security: (oonc'ptualizing the Linkages (Rome: FAO. 2002): Shatw. Horld Food Se'curts:

12. Amartya Sen. "Ingredients of Famine Analysis: Availability and Entitlements." Quarter/y Journal of Economics 96, no. 3 (1981): $+33-464$.

1.3. The current definition is: "Food security exists when all people. at all times. have physical. social and economic access to sufficient, safe and nutritious food which meets their dietary needs and food preferences for an active and healthy life." Ciled in Rome Declaration on World food Security (Rome: FAO, 1996). www. lao.org/docrep/003/w361.3e/w.361.3e(0).htm (accessed 24 February 2011).

14. See Carmen G. Gonzalez. "Institutionalizing Inequality: The WTO Agreement on Agriculture. Food Security, and Developing Countries," Columbia . Immmal of Envirommental Law 27 (2002): 431-487: Ilarmon Thomas, ed., Trade Reforms. and Fond Serarity: Country Case Studies and Symhesis (Rome: FAO, 2006).

15. Robert Wolfe. Farm Wars: The Political Economy of Agriculture and the lmemational Trade Regime (London: Macmillan, 1998).

16. World Trade Organization, Decision on Meceswes Concerning the Possible Nergative Effects of the Reform Programme on Least-Deleloped and Not Foedimporting Dereloping Countries (Geneva: WTO). 1995).

17. The Dohat Round is the WTO's longest and most protracted round of negotiations, now in its eleventh year and still deadlocked.

18. Food and Agriculture Organization. Constitutional and Legal Protertion of the Righto food Around the World (Rome: FAO. 2010). 
19. Kall Ratustiala and David Victor. "The Regime Complex for Plant (ienetic Resources." Intermational Orgamization 58. no. 2 (20)(1): 277 .31)9.

20. See ibid.: Karen Nlter and Sophic Meunier. "The Potitics of Regime Complexity," Perspertives on Politics 7 . no. 1 (20(109): 1.3-24.

21. I treat the international food aid regime as embedded within the international food security regime because of its shared institutional and normative origins in world humger eradication efforts. The politices of food aid and of agriculture trade politics hate a long history that dates hack to the 1950s with the creation of the Focs Principles of Surplus Disposal as a result of concerns by ('anada. Australia. Argentina, and other gram exponters that $\mathrm{L}$ s food ad was displacing commercial sales in third markets. In the early GATT negotiations, states agreed to heep food aid and agricultural trade issues out of the rade regime. most significantly at the (iATT Kennedy Round 1964-1967), which initiated the creation of the FAC wo resolve trade tensions over food ad outside the multilateral mading system. By the late 1980s and eatly 1990s. most donors with the exception of the Lnited States began to untic their international food aid from domestic agriculture. During the negotiation of the $A$ A, trate officials" work on food atd rules was meant to prevent any loopholes on export subsidies. It is unlikely that negotiators could have foreseen the extent of the WTO's present atuthority over food security.

22. Jennifer ('lapp. Henger in the Balaned: The New Politics of International

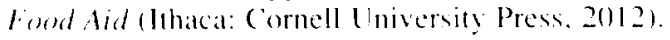

23. Rohyn Eckerseley: "The Big (hill: The WTO) and Multilateral Environmental Agreements." (ilohal Finiremmental Politica 4. no. 2 (20)(1): 24 50: Mark Axelrod, "Savings (lauses and the "Chilling Effect": Regime Interplity as Constraints on International (iovemance/latw," in Sebastian Oberthiir and Olav Schram Stokhe.

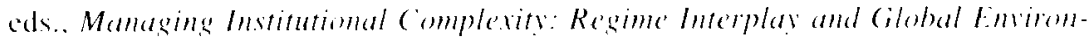
mental Change (Cambridge: MIT Press. 2011). pp. 87-114.

24. John Hoddinott. Ware Cohen. and Christopher Barretl. "Renegotiating the

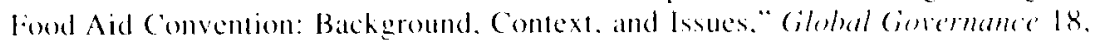
II). $3(2008): 283.304$.

25. World food Program. "Don't Play with Our Food," Financial Times. It December 2005: Simone Heri and Christian Haberli. "Can the World Trade Orgatnization Ensure That Food Aid Is Genuine"." NC CR Trade Working Paper Series 2(109/19 (Bern: World Trade Institute, 20(09).

26. WTO Director General Pascal Lamy. "Doha Round Can Help Lift Africats Agriculture." 21 lebruary 2011. www.wto.org/english/news e/sppl e/sppl188 e.htm (accessed 24 Fehruary 2011 ).

27. See Rubert Howse and Ruti Teitel. Bevend the Divide: The Cerremant an

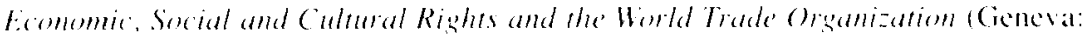
Friedrich-l:bert-Stiftung. 2007): Susan Aaronson. "Seeping in Slowly: How Human Rights Concerns Are Penetrating the WTO." Horld Trade Review 6. no. 3 (2007): $41.3-44 \%$.

28. See Rohert \%oellich. "Iree Markets ('an Still Feed the World," Finameral Times. 5 January 2011 : Pascal Lamy, "Trate Is Pant of the Answer. Vor Part of the Problen." specel given al Berlin Agriculture Ministers" Summit. 22 Jantary 2011. www.whorg/english/news_e/sppl e/sppl183__.htm taccessed 2t february 2011). 